\title{
THE EFFECT OF ROAD INFRASTRUCTURE DEVELOPMENT ON THE WELFARE OF THE COMMUNITY IN KAYU ARA VILLAGE, TULUNG SELAPAN REGENCY, OKI REGENCY, SELATAN SUMATRA
}

\author{
${ }^{1}$ Sindy Astuti*, ${ }^{2}$ Ranti Yusmania, ${ }^{3}$ Nesha Alifia Jauzi, ${ }^{4}$ Maya Panorama \\ 1,2,3,4 UIN Raden Fatah Palembang \\ Email: 1930602168@ radenfatah.ac.id*
}

\begin{abstract}
The development of facilities and infrastructure in South Sumatra has been very good and has also been realized. however, in some villages, road infrastructure development still needs more attention, especially in Kayu Ara village, Kec. Tulung Selapan Kab. OIC South Sumatra. The existence of infrastructure is a very important thing especially regarding the construction of roads, because one of the daily needs to carry out various activities such as school, work is even very important if there is an emergency such as giving birth, shortness of breath and so on. However, until now the village has not been touched by the attention of both the OIC governor and the regional government. The data used in this training is primary data obtained from the party providing information directly and has not been processed. By researching directly in the field and asking various questions to respondents. With this research, it is hoped that the government will pay more attention and provide solutions that are right on target.
\end{abstract}

Keywords: Infrastructure, economic growth, South Sumatra, primary data

\section{PRELIMINARY}

Economic development is a process of increasing total income and per capita income by taking into account population growth and accompanied by fundamental changes in the economic structure of a country and income distribution for the population of a country. Economic development cannot be separated from economic growth (economic growth); Economic development encourages economic growth, and conversely, economic growth facilitates the process of economic development.

In carrying out economic development, it cannot simply be implemented, but several supporting conditions are needed. The main requirement in development is the existence of government and people. Development depends on the government and the people. Development cannot run if only one is running. So development is basically from the people for the people. The people are sovereign, so naturally it is the people who enjoy the results of development.

Development that is only carried out by one party or forced, meaning that it does not involve the people in the real sense is not an ideal development model. This kind of development can occur, but in conditions where the system of government is dictatorial. The dictatorial development model will only give birth to the suffering and misery of the people, therefore a balanced or ideal development model is a development model that involves and is fully supported by the people. This support is in the form of participation. If development is only carried out by the government, that is, relying entirely on the government, then it is certain that development will not achieve the desired target, therefore the participation of the community is very important.

The population is an asset in development, considering the population as an agent of development, so it is not an 
exaggeration to say that the success or failure of development is determined by the attitude of the population during the development process.

What is meant by economic growth is the process of increasing the production capacity of an economy which is manifested in the form of an increase in national income. A country is said to experience economic growth if there is an increase in real GNP in that country. The existence of economic growth is an indication of the success of the economic development. ${ }^{1}$

Entering the second quarter of 2021, the South Sumatran economy is expected to improve in line with the recovery of world and domestic economic activity after the vaccination process begins in early 2021. In addition, the ratification of Law No. 11 of 2020 concerning Job Creation is believed to be able to become a game changer that can restore confidence business sector. Various economic indicators in April 2021 have shown continuous improvement. Going forward, Bank Indonesia will continue to strengthen coordination with local governments and stakeholders to closely monitor the dynamics of the spread of the COVID-19 pandemic and its impact on the South Sumatran economy from time to time as well as the coordination steps that need to be taken to maintain economic stability and support economic growth. stay good and durable.

This can also be seen from the number of unemployed which is increasing day by day, especially in South Sumatra. Unemployment is generally caused because the number of the workforce is not

${ }^{1}$ Strum, JE, Kuper G.H and De Haan. J.,

Modeling Government Investment and Economic Growth on proportional to the number of jobs that are able to absorb it. Unemployment is often a problem in the economy because with unemployment, productivity and income of the people will be reduced so that it can cause poverty and social problems more.

The unemployment rate can be calculated by comparing the number of unemployed with the number of the labor force expressed in percent. The absence of income causes the unemployed to reduce their consumption expenditure which causes a decrease in the level of prosperity and welfare. Prolonged unemployment can also have a bad psychological effect on the unemployed and their families .

Unemployment rates that are too high can also lead to political, security and social chaos, thereby disrupting economic growth and development. The long - term result is a decrease in GNP and per capita income of a country .

In developing countries such as Indonesia , the term "underemployment" is known, in which more work can be done with fewer workers.

Many companies have been established in the villages to help the welfare of the community. However, it has not been supported by adequate road infrastructure. For example, the road infrastructure in Kayu Ara Village, Tulung Selapan District, OKI Regency, South Sumatra is still in a worrying condition. The government is not quick enough in handling road construction in the village, so that to meet daily needs in activities such as, going to school, working, even if there is an emergency situation such as giving

A Macro Level: A Review. CCSO Series

No. 29 
birth, shortness of breath and so on, it is less comfortable and constrained. The following is a map and condition of the Kayu Ara village road, Kec. Tulung Selapan, Kab. OIC South Sumatra:

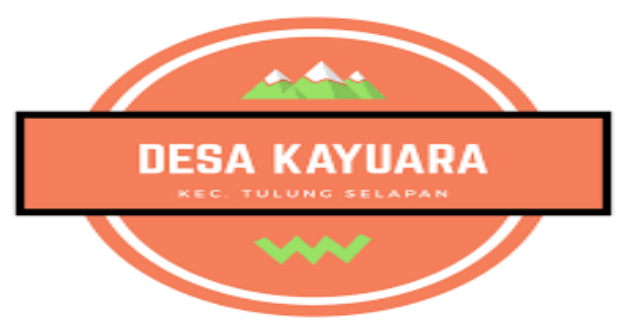

Figure 1. Ara Kayu Wood Village Logo

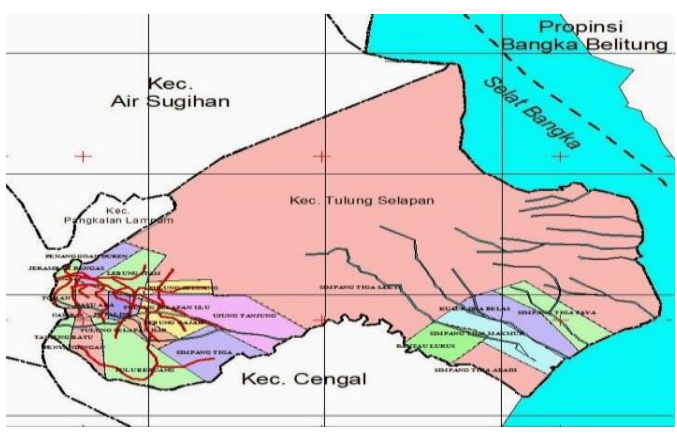

Figure 2. Map of Kayu Ara . Village
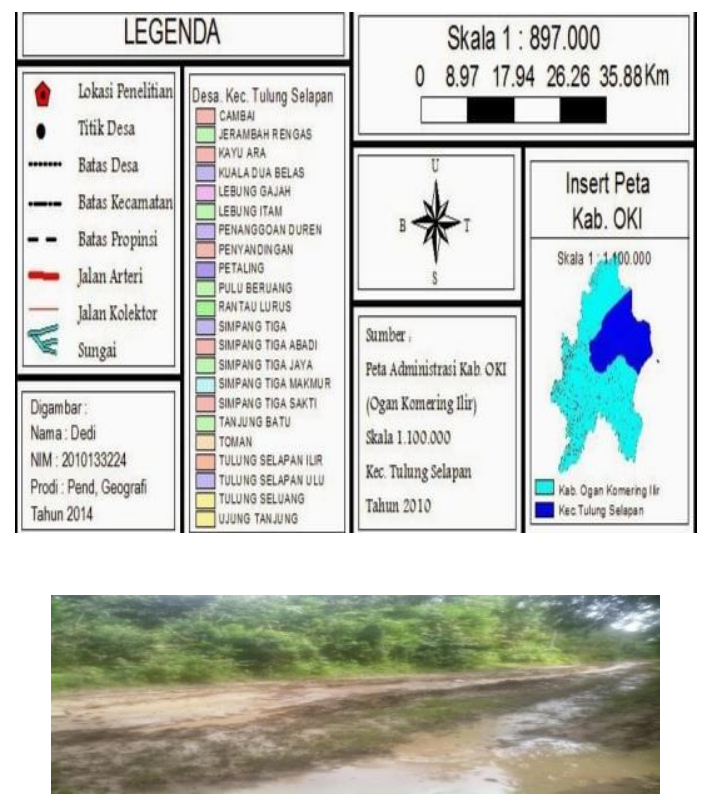

Figure 2. Road condition in Kayu Ara . Village
From the map above, it can be seen the condition of a small village with inadequate road infrastructure. This makes it difficult for people to carry out activities such as school, work and even for treatment. Although this village has been around for a long time, the provincial level roads are very worrying.

With this research article, it is hoped that the government will pay more attention to the condition of the village road infrastructure in Kayu Ara, Kec. Tulung Selapan. OKI Regency, South Sumatra so that road infrastructure is evenly distributed towards the welfare of the people of Kayu Ara village, Kec. Tulung Selapan, OKI Regency, South Sumatra has been well realized.

\section{THEORETICAL BASIS}

\section{Classical Economic Growth Theory}

\section{Robert Solow}

Robert Solow is an economist who won the Nobel Prize in 1987. Solow argues that economic growth will be achieved if there is growth in output. Output growth occurs when two input factors, namely capital and labor are combined, while the technological factor is considered constant (unchanged). As for which is classified as capital is raw materials, machinery, equipment, computers, buildings and money. In producing output, capital and labor factors can be combined in various 
combination models. So, it can be written in the following formula: ${ }^{2}$

$\mathrm{Q}=\mathrm{f}(\mathrm{CL})$

Description:

$\mathrm{Q}=$ Amount of output produced

$\mathrm{f}=$ Function

$\mathrm{C}=$ Capital (capital as input)

$\mathrm{L}=$ Labor (labor, as input)

The above formula states that output (Q) is a function of capital (C) and labor (L). This means that the level of output depends on how to combine capital and labor.

\section{Economic Development}

Economic development is a process of increasing total income and per capita income by taking into account population growth and accompanied by fundamental changes in the economic structure of a country and income distribution for the population of a country. Economic development cannot be separated from economic growth (economic growth); Economic development encourages economic growth, and conversely, economic growth facilitates the process of economic development.

\section{Economic growth}

Economic growth is a condition where there is an increase in income that occurs due to an increase in production of goods and services. This increase in income is not related to an increase in population, and can be judged from an increase in output, increasingly developing technology, and innovation in the social sector. ${ }^{3}$

\section{Adam Smith}

Adam Smith argues that economic growth is a change in the level of the economy experienced by a country that depends on the development of the population. With the development of the population, the results of a country's production will also certainly increase.

\section{Budiono (1994)}

Budiono explained that economic growth is a process of increasing per capita output in the long term that occurs when there is an increase in sources originating from the internal processes of the economy itself and has a temporary nature. That means, the growth has a self-generating nature that is able to give birth to a momentum or strength for the sustainability of economic growth in the next period.

\section{Infrastructure}

Understanding Infrastructure according to the American Public Works Association (Stone, 1974 In Kodoatie, R., 2005), are physical facilities developed or required by public agencies for government functions in water supply, electric power, waste disposal, transportation and similar services to facilitate social and economic goals.

Meanwhile, another definition of infrastructure according to the regulation of the President of the Republic of Indonesia Number 38 of 2015, infrastructure is the technical, physical, system, hardware and software facilities needed to provide services to the community and support the network

${ }^{3}$ Canning D,A Database of World Infrastructure Stocks 1950-1995. The World Bank, PolicyResearch Working Paper No. 1929

\footnotetext{
${ }^{2}$ Kindleberger and Peter H. Lindert,International Economics,Six Edition, Richard D. Irwin,Inc, Homewood, Illinois, 1978.
} 
structure so that the economic and social growth of the community can run well.

According to the President of the Republic Indonesia regulation number 38 in 2015, the economic and social infrastructure type include: 1) Transport infrastructure; 2) The road infrastructure; 3 ) Infrastructure of water resources and irrigation; 4) Infrastructure drinking water; 5) Infrastructure centralized wastewater management system;6) Infrastructure local waste management system; 7 7) Infrastructure waste management system; 8) telecommunications and information infrastructure; 9) Infrastructure electricity; 10) The infrastructure of oil and gas and renewable energy; 11) Infrastructure energy conservation; 12) Infrastructure urban facilities; 13) The infrastructure of educational facilities; 14) Infrastructure facilities and infrastructures of sports and arts; 15) Regional Infrastructure; 16) tourism infrastructure; 17) health infrastructure; 18) Infrastructure penitentiary; and 19) Infrastructure public housing. ${ }^{4}$

\section{Road infrastructure}

The road, moreover, is a basic human need that is very important and is needed as a means of connecting one place to another. With good road access and easy access, it will be easy to carry out economic activities. In addition, it is very beneficial for the welfare of the community from the liberation of remote areas by providing convenience in providing road access. This means that roads are the most important infrastructure in the national economy.
According to Law Number 38 of 2004 in Sudaryadi, 2007) concerning roads, it is stated that:

1. Roads as part of transportation infrastructure have an important role in the economic, socio-cultural, environmental, political, defense and security fields and are used for the greatest prosperity of the people.

2. Roads as an infrastructure for the distribution of goods and services are the lifeblood of the community, nation and state.

3. Roads as a unified road network system connect and bind the territory of the Republic of Indonesia.

In this case, the government should provide the best service for the community with a good road infrastructure that will affect the welfare of the community. Otherwise, it will affect the welfare of the people, social mobility will occur, and economic activities will be hampered. In addition, good road quality also plays an important role because poor road quality will reduce the pace of the economy and economic growth.

According to Moteff in Prapti, Suryawardana and Triyani, 2015 states that infrastructure is not limited only from an economic point of view but also defense and government sustainability. If a country experiences a lack of infrastructure, it will cause many people to live cooped up in isolated areas with very severe poverty levels. Therefore, infrastructure has a positive role in economic growth (J'afar M in Prapti, 21 Suryawardana and Triyani, 2015). And the government must also prepare infrastructure

Fiskal(Studi Kasus Kapet Pare-Pare), Artikel Kajian Ekonomi dan Keuangan vol.8 no.1
${ }^{4}$ Samosir, P. Agunan dan Wibowo Tri, 2004.Analisis Efektifitas Pemberian Insentif 
that is able to encourage the improvement of people's living standards in the long term.

\section{DEVELOPMENT OF HYPOTENSIS}

The influence of roads on economic growth in Kayu Ara village, Tulung Selapan subdistrict, OKI Regency, South Sumatra

The road is one of the links between one region and another. Roads are one of the things needed for land transportation for humans as well as playing an important role in the economy. This can be interpreted that the road becomes something important in making a significant contribution to economic activity by influencing the ups and downs of economic growth. ${ }^{5}$

The research conducted this time has the theme "The effect of road infrastructure development on the welfare of the people of Kayu Ara Village, Tulung Selapan District, South Sumatra Province." concluded that the road affects economic growth if the road is increased then economic growth will also increase. Based on various studies from the results of researchers, the following hypotheses are formulated:

H0 3 = Roads have no effect on economic growth in Kayu Ara Village, Tulung Selapan District, South Sumatra Province. Ha 3 = Roads affect economic growth in Kayu Ara Village, Tulung Selapan District, South Sumatra Regency.

\section{Research methodology}

The type of research in this research is descriptive qualitative. The descriptive analysis aims to explain the development of road infrastructure infrastructure on the welfare of the people of Kayu Ara Village, Tulung Selapan District, South Sumatra Province. Meanwhile, qualitative analysis is used to explain the influence between infrastructure variables and economic growth variables

The data used in this training is primary data obtained from the party providing information directly and has not been processed. By researching directly in the field, and asking various questions to respondents. With this research, it is hoped that the government will pay more attention and provide solutions that are right on target.

\section{Results and Discussion}

Ara. Wood Village Profile

The profile data of Kayu Ara Village that was taken covers the geographical location, area, and administrative boundaries, as well as community welfare.

\section{Geographical Location, Area and} Administrative Boundaries

In this study, the remaining wilayat is the administrative area of Kayu Ara Village, which is one of the villages located in the Tulung Selapan sub-district, Kab. Ogan Komring Ilir. Kayu Ara village is 400 kilometers from the capital. Kayu Ara village has an area of 200 hectares and a residential area of 20 hectares consisting of 5 guards. With regional boundaries as follows: North : Cambai Village

East : Jerambah Rengas Village South side : Kuala Twelve Village West Side : Lebung Gajah Village

${ }^{5}$ Keputusan Presiden No. 3 Tahun 2006

tentangTim Nasional Peningkatan Ekspor dan Peningkatan Investasi 
The topography of Kayu Ara village, river flow and located at a height of land from seawater settlements of . 0.023 meters ground level $0-4$ and an average temperature of 25 degrees Celsius.

\section{Total Population of Kayu Ara . Village}

Based on data from the population of Kayu Ara Village as many as 1000 people with the number of family heads (KK) 590 KK Consisting of 8 Rukun Neighbors (RT) the data was obtained in 2021 on the deduction of the Sustainable Development Goals (SDGs).

\section{Table 1}

\section{Total population}

\begin{tabular}{|l|l|l|l|l|}
\hline \multirow{2}{*}{ No } & \multicolumn{2}{|l|}{ Resident } & \multirow{2}{*}{ Total } \\
\cline { 2 - 4 } & RT & Pr & LK & \\
\hline 1 & I & 55 & 75 & 130 \\
\hline 2 & II & 60 & 69 & 120 \\
\hline 3 & III & 60 & 55 & 115 \\
\hline 4 & IV & 85 & 50 & 135 \\
\hline 5 & V & 60 & 65 & 125 \\
\hline 6 & VI & 40 & 85 & 125 \\
\hline 7 & VII & 50 & 50 & 100 \\
\hline 8 & VIII & 80 & 70 & 150 \\
\hline
\end{tabular}

Table 1 describes the population in Kayu Ara village in RT I with a population of 130 people, in RT II with a population of 120 people, in RT III with a population of 115 people, and in RT IV with a total population of 135 people. RT $V$ has a population of 125 people, RT VI has a population of 125 and RT VIII has a population of 150 people. So the total is 1000 people in March 2021. Which consists of VIII Rukun Tetangga (RT). In this evaluation stage, the respondent gives participation in property and objects in the form of food and beverage donations such as cakes and drinks. This is because the community life in Kayu Agung Village is still very strong, especially in sharing with others. The habit of gotong royong is still attached to every village community.

However, in terms of science and technology, the community is very underdeveloped, this is because the village is far from civilization. Even to just go out for treatment at the hospital, people have to travel a distance of 6 hours to the capital with very poor road conditions. From the information obtained from a respondent named Pak Jarwo, the community prefers to seek treatment from a traditional healer rather than a hospital. Because of the distance and also the costs incurred to go for treatment. Then there is still a lack of health workers in the village there is only one midwife who lives in the Village Health Center (PUSKESDES).

\section{Education}

According to the respondent, Mrs. Lina Mardina, education in Kayu Ara Village is considered very poor at the high school level, for elementary school and high school the questions are already available in the village. The distance to high school is about 3 hours by a very bad road. Then the distance to the college is about 6 hours from the village. Therefore the children in the village prefer not to go to school and help their parents go to the garden. Due to low education, literacy rates are very low. And also the welfare is very low in the village. The thing that is very concerning is that early marriage is the main choice for teenagers who are there. With the aim of being able to continue living. In fact, it should only add to the burden on teenagers' lives. Those who should still have to gain knowledge but prefer 
to be a wife/husband figure and even a mother/father figure. The age range of adolescents who marry early is $13-18$ years. The age where their emotions are very high. Not a few cases of divorce that occurred in Kayu Ara Village due to domestic disputes.

Then in Kayu Ara Village, Kawin Lari is one of the habits that always occurs before the wedding. People have considered it normal and also normal for teenagers to do. Elopement culture is carried out by visiting the house of the village head from another village and they ask the village head for help to call their two people and get married. Then the village head called the parents of both parties. Before the parents or relatives of both parties arrived, the village head would not allow them to return to their respective homes. The guardians of both parties must first pay a ransom in the form of money to the village head before they can bring their children home. Each village has a different ransom fee, some 400 thousand a day, some 500 thousand depending on the village's provisions.

This became the center of one of the centers of attention that we examined because the children's interest in going to school was no longer there. They think that they don't need to be highly educated to live. Just eating for today is already quite extraordinary. Thoughts that are still too primitive compared to the people in the Capital.

\section{Village Livelihood}

The livelihood of the majority of the villagers is by tapping rubber which is sold to middlemen at very low prices. The community has no other choice but to sell the place. Not only that, the community also has no other livelihood. If it rains, people cannot go to the rubber plantation. And just stay at home. The level of community welfare is very poor because the road access has never been repaired and is far from civilization. The number of poor families continues to increase in Kayu Ara Village.

Table 2

Number of Beneficiaries from SDGS Enumeration

\begin{tabular}{|c|c|c|c|c|c|}
\hline $\begin{array}{l}\mathbf{N} \\
\mathbf{O}\end{array}$ & $\begin{array}{l}\text { Help } \\
\text { Type }\end{array}$ & RT & $\begin{array}{c}\text { Numb } \\
\text { er of } \\
\text { Recipi } \\
\text { ents }\end{array}$ & $\begin{array}{l}\text { Help } \\
\text { form }\end{array}$ & $\begin{array}{l}\text { Help } \\
\text { value }\end{array}$ \\
\hline 1 & PKH & I & 30 & $\begin{array}{l}\text { grocerie } \\
\mathrm{S}\end{array}$ & $\begin{array}{l}200 \times 9 \mathrm{~m} \\
\text { onth }\end{array}$ \\
\hline 2 & $\begin{array}{l}\mathrm{BPN} \\
\mathrm{T}\end{array}$ & II & 10 & $\begin{array}{l}\text { grocerie } \\
\mathrm{S}\end{array}$ & $\begin{array}{l}200 \times 9 \mathrm{~m} \\
\text { onth }\end{array}$ \\
\hline 3 & $\begin{array}{l}\text { BST } \\
\text { BA } \\
\text { NK }\end{array}$ & III & 5 & $\begin{array}{l}\text { Transfe } \\
\mathrm{r}\end{array}$ & $\begin{array}{l}600 \times 3 \mathrm{~m} \\
\text { onth }\end{array}$ \\
\hline 4 & $\begin{array}{l}\text { AST } \\
\text { PT } \\
\text { POS } \\
\text { T }\end{array}$ & IV & 2 & Cash & $\begin{array}{l}600 \times 3 \mathrm{~m} \\
\text { onth }\end{array}$ \\
\hline 5 & $\begin{array}{l}\text { PRO } \\
\text { VIN } \\
\text { CE }\end{array}$ & V & 3 & $\begin{array}{l}\text { grocerie } \\
\mathrm{S}\end{array}$ & $\begin{array}{l}200 \times 3 \mathrm{~m} \\
\text { onth }\end{array}$ \\
\hline 6 & $\begin{array}{l}\text { DIS } \\
\text { TRI } \\
\text { CT }\end{array}$ & VI & 3 & $\begin{array}{l}\text { Groceri } \\
\text { es }\end{array}$ & $\begin{array}{l}200 \times 3 \mathrm{~m} \\
\text { onth }\end{array}$ \\
\hline 7 & \begin{tabular}{|l} 
VIL \\
LAG \\
E \\
FUN \\
D \\
BLT
\end{tabular} & VII & 66 & Cash & $\begin{array}{l}600 \times 3 \mathrm{~m} \\
\text { onth }\end{array}$ \\
\hline
\end{tabular}




\begin{tabular}{|l|l|}
\hline $\begin{array}{l}\text { Total } \\
\text { recipients }\end{array}$ & 119 Family Head \\
\hline
\end{tabular}

From table 2, it can be seen that the beneficiaries of Kayu Ara village are almost $55 \%$ of the total population. Because the economy is very difficult, raw materials are very expensive, even the price has doubled. The total number of beneficiaries reached 119 households who received assistance from the government to support their lives.

Village communities still expect attention from the government to make improvements so that their lives and welfare can improve. Not restrained by endless troubles. Every application submitted to the district government. Just a sweet promise that never materialized. Not only that, the problem of the internet network is also very disturbing the lives of the Village Community. The people of Kayu Ara Village are still waiting for the government's kindness to immediately pay attention to this small village where there are also many generations that need education, technology and knowledge from outside. With all these limitations, people think that education is not a very important thing that must be fought for. That's the standard of village community welfare

\section{Conclusion}

Poor and unrepaired road infrastructure has damaged the livelihoods of the people of Kayu Ara Village, Kec. Tulung Selapan Kab.Ogan Komring Ilir. People's education is low, the economy is getting worse by relying on only one sector, public health is not guaranteed and also basic necessities that cost twice as much as the original price.

\section{Suggestion}

It is very much hoped that the government will immediately carry out an even distribution of road infrastructure development, not just fixing the capital or district. Because it's been decades the people of remote villages have not received the slightest attention.

\section{DAFTAR PUSTAKA}

Adioetomo dan Moertiningsih, Sri. 2005. Bonus Demografi: Hubungan antara Pertumbuhan Penduduk dengan Pertumbuhan Ekonomi. Jakarta: BKKBN.

Affandi, Yoga. 2002. "The Optimal Monetary Policy Instruments: The Case of Indonesia”, Buletin Ekonomi Moneter dan Perbankan

Ahmed, Riazuddin. 1964. Cooperative Movement in South East Asia Obstacles to Development. Dalam Dr. Mauritz Bonow (Ed). The Role o Cooperatives in Social and Economic Development. London: International Cooperative Alliance.

Ananta. 1986. Mutu Modal Manusia: Suatu Pemikiran. Kualitas Penduduk. Jakarta: Lembaga Demografi Universitas Indonesia

Budiman, Arief. 1991. Negara dan Pembangunan: Studi tentang Indonesia dan Korea Selatan. Jakarta: Yayasan Padi dan Kapas.

Canning D, A Database of World

Infrastructure Stocks 1950-1995. The

World Bank, PolicyResearch Working Paper No. 1929

Danim, Sudarwan. 2004. Motivasi, Kepemimpinan dan Efektivitas Kelompok. Jakarta: PT. Rineka Cipta. 
Danim, Sudarwan. 2006. Agenda Pembaruan Sistem Pendidikan. Yogyakarta: Pustaka Pelajar.

Drucker, Peter F. 1988. Inovasi dan Kewiraswastaan, Praktek dan DasarDasar. Jakarta: Erlangga.

Keputusan Presiden No. 3 Tahun 2006 tentang Tim Nasional Peningkatan Ekspor dan Peningkatan Investasi Konsep, Dimensi, dan Strateginya. Bumi Aksara. Jakarta

Kindleberger and Peter $\mathrm{H}$. Lindert,International Economics,Six Edition, Richard D. Irwin,Inc, Homewood, Illinois, 1978.

Samosir, P. Agunan dan Wibowo Tri, 2004.Analisis Efektifitas Pemberian Insentif Fiskal(Studi Kasus Wapet ParePare), Artikel Kajian Ekonomi dan Keuangan vol.8 no. 1

Sukirno, Sadono. 1985. Ekonomi Pembangunan: Proses, Masalah dan Dasar Kebijaksanaan. Jakarta: FE-UI.

Sugiono. 2009. Metode Penelitian Bisnis. CV Alfabeta. Bandung.

Sritua Arief. 1998. Pembangunanisme dan Ekonomi Indonesia: Pemberdayaan Rakyat dalam Arus Globalisasi. Bandung: Penerbit Zaman.

Strum, J.E, Kuper G.H andDe Haan. J., Modelling Government Investment and Economic Growth on A Macro Level:A Review. CCSO Series No. 29

Suryono, Agus. 2001. Teori dan Isi Pembangunan. Universitas Negeri Malang, UM Press. Malang

Wolf, Martin. 2004. Why Globalization Works. New Haven dan London: Yale University Press.

Young, Linda M. dan Karen M. Huff. 1997. "Free Trade in the Pacific Rim: On What Basis?”, dalam Thomas W. Hertel (ed.),
Global Trade Analysis: Modelling and Applications, Cambridge University Press.

Zeuli, Kimberly A dan Robert Cropp. 2005. Cooperatives: Principles and Practices in the 21st Century, A1457, edisi ke-4, University of Wisconsin, Madison Zuvekas, Clarence, Jr. 1979. Economic Development: An Introduction. New York: St. Martin's. 